\title{
The Place of Siyāq in the Interpretation of the Qur'an
}

\author{
Seyyed Mohammad Razavi ${ }^{1}$; Marziyeh Sa'emi ${ }^{2}$; Zohreh Shavandi ${ }^{3}$ \\ ${ }^{1}$ Assistant Professor of Islamic Azad University, Central Tehran Branch, Group of Qur'an and Hadith Sciences, \\ Tehran, Iran \\ dsmrazavi@yahoo.com
}

${ }^{2}$ Ph.D. Student of Qur'an and Hadith Sciences, Islamic Azad University, Central Tehran Branch, Tehran, Iran Marziyeh58saemi@gmail.com

${ }^{3}$ Ph.D. Student of Qur'an and Hadith Sciences, Ușūl al-Dīn Faculty, Tehran, Iran Shavandi110@yahoo.com

http://dx.doi.org/10.18415/ijmmu.v8i9.2896

\begin{abstract}
The term Siyāq (i.e. context) and its place and role in the interpretation of the Qur'an has always been considered by scholars and Qur'anic scholars. This term has been mentioned in the surviving narrative literature of the Infallibles (PBUT) as [connected word]. In fact, the principle of symmetry of the context and verbal and semantic order governing the body of the Qur'an, including verses and surahs, and even the arrangement of words and letters and their succession are among the principles inseparable from the word of God. It will help us to pay attention to this principle and applying it in the process of interpreting verses. In the current article, we try to get acquainted with the term context and its types, which are divided into contexts of words, sentences, verses and surahs, as well as its role and position in understanding Qur'anic verses, and the conditions for realizing the context and ways of proving and using it.
\end{abstract}

Keywords: Siyāq; Types of Siyāq;Functions of Siyāq; Conditions for Realization of Siyāq; Qur'an Interpretation

\section{Introduction}

One of the issues that can be seen in the discussion of the interpretation of the Holy Qur'an in the biography of the Imams and, consequently, other commentators of the Holy Qur'an is the use of "context" in the matter of interpretation. Although the extent of its use varies among commentators, but paying attention to its context and its relationship with rhetoric is always one of the evidences in understanding meaning. Authenticity of context denotation and the principle of its symmetry is one of the rational principles of dialogue; therefore, ignoring it leads to incorrect or incomplete interpretation and understanding of the verses. This is more evident in the interpretation of similar verses and it is more necessary to pay attention to it. It can be said that the main meaning of the context is to use the verses themselves to discover the desire of God. Therefore, doubtlessly, a comprehensive understanding of the context, characteristics and criteria of application and its areas of influence is a constructive step in promoting interpretive issues. Therefore, in this article, after inserting the definitions of the context and its 
importance among various scientists in this field and its position and importance in interpretation, we will explain the types of contexts, including the context of words, sentences, verses and surahs. We also examine the conditions under which context is realized, and then, by proposing methods for recognizing context, we examine examples of context applications in the field of Qur'anic sciences. As it turns out, the interpretation of the Qur'an based on context, or in other words, the contextual interpretation of the Qur'an, is comprehensive methods and criteria of interpretation and regulates all of them based on the context of the word and in this regard, is an effective method of interpreting the Qur'an.

\section{Background}

The present study has examined and analyzed the rule of context, which is one of the rules of Qur'anic verses, and has expressed its significant effect on understanding the meanings of the verses. The use of context in customary conversations and its effect in determining the meanings of words and sentences in the expression of people has been common for a long time and it dates back to Companions and followers regarding the field of Islamic thought and inference of Qur'anic truths and it can be understood in a wide area within the text and hypertext. Among the Muslim scholars, the first person who used this word with the same meaning is Muhammad ibn Idris Shafi'i (d. 204 AH). In his book Al-Risālah, he has a chapter entitled "Bab al-Șinf yubayyinu siyāquhu ma 'nā" and he has stated some points briefly about the rule of context. History shows that Muhammad ibn Harir Țabarī (AD $310 \mathrm{AH}$ ) has paid attention to the meaning of the context in the interpretation of the verses of the Qur'an and has used it for determining the scope of the content of interpretive discussions. The followings are the books and independent dissertations which have been written in this area.

A: the book Dilālah al-siyāq, a work by Mr. Al-Talhi, which has been compiled in the community of Umm al-Qurā in Mecca.

B: A treatise on comparative study of the role of context in interpretations

C: Thesis on the subject of principles and the role of context in the Holy Quran.

In the above cases, issues such as the conditions and bases of using the context, the authority of the context and its constituents and some of its functions have been addressed, but the present study has examined the role of context and its place in understanding Qur'anic verses and ways of proving and using it.

\section{Conceptology of the Word Siyāq:}

First, we examine the lexical and idiomatic meaning and validity of the word context.

\section{1-1 The Lexical Definition of the Word Siyāq:}

The origin of this word is "Sawq" and its verb is "Saq" and its original source is "Sawāq" which was transformed into "Siyāq" for morphological reasons. Linguists have given several meanings to this root. Khalil Ibn Ahmad Farāhīdī considers Sūq as infinitive which originates from Sūq that means the place of buying and selling, as God Almighty said:

"And they say: "What sort of a messenger is this, who eats food, and walks through the streets? Why has not an angel been sent down to him to give admonition with him?"'('al-Furqān/7) [Farāhīdī, 1409 AH, vol. 5, p. 190] also he knows Sawq the separation of the soul from the body, (Ibn Manzūr, $630 \mathrm{AH}$, 
vol. 10, p: 166) driving and dragging like the Sawq al-Ibil means dragging or driving camels, also means driving towards the death, as he said:

"As if they were being driven to death" (al-Anfāl /6)

“And one leg will be joined with another." (Al-Qiyāmah /29)

And the severity of death "On the Day that they are afflicted with the hardship" (al-Qalam/42) and an Aswaq man and a Sawqā woman means a man and a woman who have large legs. Al-Sawīq is drinkable because it sinks into the throat without chewing. (Isfahani, $1412 \mathrm{AH}$, p. 436) Also Sawq, means continuous string, function, style and method, secret affairs, allusion from woman's intensity and dowry, (Ibn Manzūr, $630 \mathrm{AH}$, vol. 10, p. 166) Attraction and rejection of The camel (Rāghib Isfahani, $1412 \mathrm{AH}$, p. 436), is to drive someone or something from behind, where he said, "So that they raise up the Clouds, and We drive them to a land that is dead" (Fātị / 9), like clouds to the dead land to preserve Order and the completion of grace and bounty, so this is how to drive the infidel to hell and the believer to heaven to maintain order and do justice. And in the verses "That Day the Drive will be (all) to thy Lord!" [al-Qiyämah / 30] and "An Angel who drives Him forth, and an Angel who bears him Witness" [Qāf / 21], it is accompanied by intensity and exaggeration. (Rāghib Isfahani, 1412 AH, p. 436; Ibn Manzuūr, 630 AH J 10, p: 166, Mustafawī, 1989, vol. 5, p: 271) and also is sequence and to follow each other. (Zamakhsharī, 1966, p. 314). And the "al-Sāq" is the part of the foot with which it moves, whether outwardly or spiritually, towards guidance or misguidance. And this statement is implied that the letter A of al-Sāq, being turned out of W in Sawq, which is the manifestation of motion and movement (Musțafawī, 1989, vol. 5, p. 271). Azarnoosh also considers Sāq to move forward and the Siyāq as the texture, shape, structure, text, sequence and sequence of events. (Azarnoosh, 2000, p. 310)

\section{1-2 The Idiomatic Definition of the Word Siyāq:}

Any reason connected to the word or the considered phrase and is related to it, is called context. Contexts can either be words, that is, words that form a continuous and integrated word, or they can be symmetrical, which in fact it is a situation in which the words in question are presented and it is enlightening to understand the subject (Sadr, 1392, the first circle, p. 103). The author of the commentary "Min Wahy al-Qur'an" This meaning is other than the concept that a word has regardless of other words or the text of the word. (Faḍlullāh, 1419 AH, vol. 15, pp. 440-441). Either the different meanings and limitations of the meaning that top and down of the sentences create in the each other meaning. (Gerami, 1383, p. 51) or the characteristics that create the association of words and sentences together are called context. (Mo'addab, 1392 , p. 120). Therefore, it can be said that context is a rational rule that is used in every connected word or sentence, this benefit is also in the science of interpretation, jurisprudence, principles, etc. Context, then, is the specific arrangement of words in a sentence or sentences related to a subject in a word, which is effective in determining the meaning and purpose of the speaker.

\section{1-3 The Importance of the Role of Siyāq From the Perspective of Scientists:}

In all languages, the context and its effect on the meaning of the word have been considered, and this is one of the rational and customary principles of dialogue. This was also used by commentators and scholars of Qur'anic and Islamic sciences in understanding religious texts and had a great impact on determining and interpreting the meaning of words and verses. In order to clarify the discussion and explain the attention of Islamic scholars to the context, the views of some scholars of Qur'anic sciences are mentioned. Zarkashī considers the cases that do not have a valid quotation in the interpretation of verses as referring to the meaning of the words and accuracy in its application in accordance with the existing context as the way to understand the meaning and knows Rāghib Isfahāni's action in his contents a witness of this and a factor in discovering other meanings than other lexicographer. (Zarkashī, 794 AH, vol. 2, p. 313) Sahib Al-Manār believes that agreeing the lexical meaning with the previous sections and compatibility with the set of meanings is the most important analogy that can be considered for the truth of the lexical 
meaning of the word. (Rashid Reza, 1354, vol. 1, p. 22) Others also consider it necessary to pay attention to other issues such as awareness of health and conditions of the Holy Prophet of Islam (PBUH) and his life and companions and enemies at the time of the revelation of the verses. Because it leads to the knowledge and understanding of the purpose of the Qur'an and causes general allocation, absolute restriction and variety of meanings and concise explanations. (Al-Sa'di, $1408 \mathrm{AH}$, vol. 1, p. 13) Also, the scholars of interpretation in the thematic study of verses have placed a lot of emphasis to the verses before and after that subject, and have mentioned appropriate parallels in them, so that in thematic studies, the real meanings that are obtained with the meaning of context are not neglected (Mișbāḥ Yazdī, 2007, p. 10)

\section{2- The Position and Importance of Siyāq in the Science of Interpretation}

Context has many applications in the interpretation of the Qur'an, which can be summarized as the role of context in the interpretation of words, breadth and narrowness of words, determining the meaning of sentences, critique of revelation, recognizing Makkī verses from Madanī ones, critique of interpretive hadiths, determining pronoun reference, word comprehension or The omitted sentence, determining the instance of the word and in preferring and determining one of the two readings which requires a detailed discussion .As it has been discussed the context and the principle of its symmetry is one of the rational principles that is considered for discovering meaning in all languages. Therefore, context is one of the evidence attached to the understanding of the word, which has a great function in interpretation. in other words; Context is one of the best proofs for discovering the exact meanings of verses and not paying attention to it will cause an incomplete interpretation of the Qur'an and makes it difficult to understand the verses, especially similar verses. A closer and more accurate attention to the context reveals the meaning that in fact the main meaning of the context is to use the verses of the Qur'an to understand the meaning of God's word. It can be said that there are features in the context that cause the listener's mind in the context of the context to achieve the desired concepts of mandatory and implied implications. Features such as order and unity of subject. Also, the temporal and spatial conditions inserted for the context, in addition to extracting various meanings of different words and phrases, also clarifies the meanings of the purpose. Therefore, it can be said that context is the most important and reliable tool for the interpreter to understand the verses of the Holy Quran. Therefore, paying attention to the context and appropriateness of each group of verses with each other is very important in discovering the meaning and purpose of the Quran. To make the point clearer, we will briefly state some examples.

\section{3- The Relationship between Balāghah and Siyāq:}

Rhetoric is the quality of expression of meaning with eloquent words and appropriate to the listener's mood. (Al-Kawaz, 2007, p. 69) Therefore, it can be said that rhetoric and context are two sides of the same coin. Whenever the word expresses concepts and content according to the addressee and his conditions, which are not intended otherwise, and the addressee receives it, rhetoric is projected, and whenever the word is weighed in accordance with the speaker and his conditions, the discussion is contextual. Therefore, it can be said that every eloquent speech has a context; That is, the meaning that the audience understands from the speech has been in the speaker's words. Rhetoric and context, then, mean rational speech that come together with "rational necessity." As the possessor of the spirit of meanings considers the necessity of eloquence in the direction of the goal and to avoid bringing additions except in strengthening the intention. (Ālūsī, 1415 AH, vol. 24, p. 129). It should be noted that since the audience's mood is different the speech positions are also different, such as the difference between the position of unknown from the position of known and the position of reference from the position of restriction, the position of brevity from submission or submission to the delay, the chapter on connection and the position of mention from the position of eliminating differences addressed to a wise or insane person. (Qasim; Deeb; 2003, pp. 7-8) In other words, it can be said that the relationship between context and rhetoric is the same relationship between the speaker and the addressee that the speech was issued in a specific context and the addressee Interprets and understands it based on the conditions of the speech. 


\section{4- Types of Siyāq:}

In addition to what is used in the idiomatic definition of context, scholars have listed the following types of context:

\section{4-1 Siyāq of Words:}

Consecutive words that come together in a sentence and express the same meaning create the context of the words. This type of context is a strong analogy for limiting the meaning of words and understanding the sentence. For example, if someone says that a lion ate a man, the meaning of lion limits to a predator and the meaning of the word is revealed. Therefore, the context of words is one of the most important evidences of context. There are many instances of this example in the Holy Qur'an that have been able to determine and limit the meaning of words. For example, in the Qur'anic verse, "The Absolute Sovereign of the Day of Judgement." (Al-Fātihah /4) the context of the word is "religion", which means "punishment". Because in this context, "Master" has been added to the word "Day" and then "Master of the Day" to "Judgement" and has given it the exact and clear meaning of "punishment". While the original meaning, without its addition, does not convey this meaning. (Rajabi, 1394, p. 125). Other examples include the gathering of "other relatives", "orphans" and "the poor" in verse 8 of Surah An-Nisā', which is clarified in the meaning of "other relatives" by the relatives of the deceased who do not inherit from him. (Faḍlullāh, $1419 \mathrm{AH}$, vol. 7, p. 100) Also the gathering of "Furqān" (i.e. a power of distinction between right and wrong) with "piety" in verse 29 of Surah al-Anfâl will indicate the meaning of separation between right and wrong for the criterion, not for absolute separation (Ibid., Vol. 10, p. 366).

\section{4-2 Siyāq of Sentences:}

This means that in a verse, the sentences are also symmetrically semantic and will affect each other to clarify the speaker's purpose. This has been considered by many great commentators such as Țabarī, who in his commentary on the verse of Âyat al-Kursī says that the meaning of the phrase "No slumber can seize Him nor sleep" is the emphasis and explanation of "the Self-subsisting" which is preceded by "Allah. There is no god but He, the Living, the Self-subsisting, Supporter of all. " Because the one who is sleepy and drowsy is not "the Self-subsisting" (the one who rises to do something) (Țabarī, 1375, vol. 1, p. 331 / Arafat al-Warghami, vol. 1, p. 310).

\section{4-3 Siyāq of Verses:}

Regarding the Holy Quran, the context of the verses is obtained by following the verses. According to the explanation of the previous two types, and considering that some verses include several sentences, such as the verse of Āyat al-Kursī, which was described in the context of the sentences, and some verses have a word and a clause, such as "The color of the two Gardens is Dark-green"; (Ar-Rahmān 64) can be said that their context, like the context of words, has been clarified and accepted without any conditions. Therefore, the principle of symmetry of the context of the verses is unquestionable. Seyyed Razi, in rejecting the opinion of the one who said that God's desire from the Qur'anic verse "You give the kingdom to whomsoever You Will" (Āl-'Imrān/26) is the king of Paradise, does not like it and believes that the context of the sentences in this verse and the next verse shows that this granting property and taking it only took place in this world and is not related to the Hereafter. Because he continued "You exalt Whomsoever You Will and abase Whomsoever You Will." which is all related to this world and has nothing to do with the Hereafter. (Sharif al-Radhi, 359 AH, pp. 65 - 66). The symmetry of this type of context, with two conditions accepted by the commentators of the Holy Qur'an, will come

\section{4-4 Siyāq of Surahs:}

As it is clear from its naming, this context is obtained by following the Surahs. There are different views in this category. Some scholars of Qur'anic sciences consider the chapters of the Qur'an to be related. 
That is, they have expressed the aspect for the proximity of the surahs to each other and the connection of the first verse in each surah with the last verse of the previous surah, which is the context of the surahs. Because they consider the order of the surahs to be forbidden. One of these scholars is Subhị Saleh, who believes that the order of the chapters of the Qur'an, as the same order that is available to us today, is just like the order of the verses in each surah of the forbidden Qur'an, and is by no means ijtihad (Șubhī, 2014, p. 107). But he considers it necessary to connect the final verses of a surah with the first verses of the next surah to be thematic similarity. Otherwise, this connection is not reasonable and there is a difference between the thematic unity of a surah and the claim of thematic unity of the whole Qur'an. (Ibid., P. 229) Some other scholars of Qur'anic sciences reject this idea and state that the surahs have not been collected and arranged according to the order of revelation. Therefore, the order of the surahs in the Qur'an is ijtihad. They have no valid and justified reason for the confinement of the order of the surahs. They do not consider the citation of the context of the surahs to be valid according to the command of the Holy Prophet (PBUH) and as a result, the relationship between the contexts of the neighboring surahs is not acceptable (Mo addab, 1392, p. 113). On the other hand, according to the teachings of Outstanding Exemplar ${ }^{2}$, the verses of the Holy Qur'an can be in the same group in different ways, and sometimes they are pairs, which have been narrated through narrations, and sometimes it has found its way into the rules of jurisprudence. Like the necessity of reciting both "li Ilāf Quraysh" or "al-Duhạa" and "Alam Nashrah" "together. Therefore, according to the author these points can be considered in the discussion of the context of Surahs.

\section{5- Conditions for Realization of Siyāq:}

The realization of the context of the verses as well as the realization of the context of the sentences depends on the fulfillment of the two conditions of the existence of the issuance relation and the thematic relation, which we will briefly describe.

\section{5-1 Issuance Connection or Continuity in Revelation:}

Consistency in revelation, which is also called issuance connection, means that sentences and verses should be expressed and examined in the same way and in the same order as they flowed in the tongue of the speaker, without disturbing their continuity. The issuance of words with appropriate meanings from the wise speaker is the criterion of the symmetry of the context, and it is established when they have coherence and connotations at the time of the issuance of the material, which is also called coherence in revelation. And if this exponential relationship between sentences is not clear, there seem no a context between the sentences to consider it as a connected analogy for understanding the meaning of words and sentences. It will also be used as a discontinuous analogy if a single person is saying the same thing, even if it is at different times or in different contexts. While continuity in revelation is a continuous evidence and has a higher impact on word comprehension.

Therefore, there are two ways in issuing verses of the Holy Quran. Either all the verses of the Holy Qur'an are issued in the order of the existing Qur'an, or in some of the verses and sentences, the order is other than the order of revelation. In the first case, there is no need to examine the issuance connection in each verse, and in the second case, the issuance connection of verses and sentences with the verses and sentences before and after them is not definite and their issuance connection must be established so that the context can be used to understand them. Among the commentators of the Holy Quran, Allameh Tabataba'i emphasizes the existence of such a connection between the verses and cites the unity of context to the unity of revelation. He considers the context of the verses of Surah al-An'ām to be connected and unified and as a one-time revelation of this Surah. (Tabataba'i, 1350, vol. 1, p. 5). He also considers 190-195 of surah alBaqarah to have a single revelation because of its context which is about fighting and dealing with polytheists. (Ibid., Vol. 2, p. 60). He uses the context between the verses to understand the order of revelation and the choice of one of the readings among the various readings, which is for the internal

\begin{tabular}{ll} 
& (سوه حسنه 2 \\
\hline The Place of Siyāq in the Interpretation of the Qur'an & 153
\end{tabular}


coherence of the verses and their relationship and connection with each other. (Ibid., Vol. 20, p. 40 and vol. 5, p. 376, vol. 2, p. 159).

\section{5-2 Thematic Connection:}

The second condition for the context of the verses to be symmetrical is that their thematic connection should be the same or that they should come together. Since the order of the verses in the current Muṣhaf is "restrictive" and except in certain cases it is in accordance with the order of revelation, it can be said that all the verses have a single origin and content coherence. Ayatollah Ma'refat believes that the interpretation of verses in the surahs should be done on the basis of the originality of the context, and the first principle is that the current order of the verses in the surahs is the very order of revelation, unless proven otherwise. (Ma'refat, 1388, vol. 1, p. 280) Allameh Tabataba'i says about the following verse "So ask the learned of the people of the Book if you people do not know about it" (Nahl/43) that according to the context, the polytheists are addressed in this verse. He also says in the following verse "And verily, there came Our Divine Emissaries to Ibrahim with glad-tidings." (Hūd / 69): It can be understood from the context that the good news in this verse is the annunciation of the existence of Isaac. Regarding the honored verse, "And verily, there came Our Divine Emissaries to Ibrahim with glad-tidings." (Hūd / 96) Allameh also says: "According to the story of Prophet Moses (PBUH) in different chapters of the Qur'an, the meaning of (verses) in the mentioned verse is the very extraordinary deeds that were performed by him. (Tabataba'i, 1350, vols. 12 and 10, pp. 380 and 285) Another example that late Tabarsi states is related to verses 16 to 19 of Surah Al-Qiyāmah, which are among the verses that are on the subject of Resurrection and its circumstances, in the form of protesting sentences about the revelation of the Holy Qur'an and the action of the Holy Prophet (PBUH) in receiving revelation. He is against the fact that due to the resurrection context, the appearance of the verses in its interpretation has been omitted and it should be considered as the subject of the letter of deeds and its reading. He considers the root of this mistake to be ignoring the mentioned condition (Tabarsi, 548 AH, vol. 10, p. 197; Tabataba'i, 1350 AH, vol. 20, p. 111).

\section{6- Ways to Prove the Rule of Siyāq:}

To prove the certainty of the context rule, three reasons can be enumerated that will come.

\section{6-1 Originality of Siyāq:}

As mentioned before, in the verses of the Holy Quran, either the issuance and thematic connection among the verses is definite and clear, or it can be concluded from other evidences such as the narrations for the dignity of revelation, the content of the verses, the style of expression, the status of the word, etc. that the context is realized and should be acted upon. Also, in cases where the objection of some sentences or the independence in the revelation of some verses is proven for valid reasons, the context should not be relied upon. In the second case, if the continuity of the verses in the revelation or the thematic unity of the verses is not definite and is not proven by the mentioned ways, the "originality of context" can be proposed as a solution in this field. The author of the book "Al-Tamhīd" believes in this regard that "the originality of the context" should not be neglected in the verses. Because the basic principle is that the current arrangement is the same as the revelation arrangement, unless proven otherwise. There are not many cases that are outside their original position except for a few cases, and that is because it was ordered by the Holy Prophet (PBUH), it has a reason and occasion which is enough to benefit from the context. Therefore, the connection of verses, sentences and words with each other and the symmetry of each for the other is structurally based on content. Therefore, it can be said that even in cases where the relationship between successive sentences and verses is questioned, the principle is based on their connection and the originality of context, and the interpretation of verse will be appropriate to it. (Knowledge, 2009, vol. 1, p. 280; Ibid: vol. 5). 


\section{6-2 Seizure of the Current Order of Verses:}

In the Holy Quran, there are cases of verses whose order is contrary to the revelation of the Quran. In these cases, there are two views among scholars of Qur'anic sciences. Some consider this arrangement of verses as restrictive and some deny its confinement and consider it as a product of the ijtihad of the Companions (Tabataba'i, 1350, p. 113). However, most scholars of the Qur'an consider the order of the verses to be restrictive and claim consensus on it. (Ālūsī, $1415 \mathrm{AH}$, vol. 1, p. 26, Bahrani, $1100 \mathrm{AH}$, vol. 3, p. 353; Suyūṭi 1421 AH, vol. 1, p. 194) Due to this, those verses whose arrangement is contrary to revelation will also have an effect for their restrictive arrangement and will be noticed and effective in determining the meaning of words and sentences. Will be and is effective in determining the meaning of words and sentences. Therefore, it can be said that the dispersion in the order and arrangement of the verses is the same as the continuous verses in revelation and their context is as valid as the context of the continuous verses in revelation. The confinement of the order of the verses is also a continuum in their revelation and plays the same role in proving the rule of context.

\section{6-3 Confirmation of Reference to the Current Qur'an:}

In the teachings of the Holy Prophet (PBUH) and the guidance Imams, adhering to the Holy Qur'an is the source of prosperity and salvation for human beings. The Prophet (peace and blessings of Allāh be upon him and his family) said: "When seditions surrounded you like pieces of a dark night, turn to the Qur'an.... (Kulaynī, 232 AH, vol. 2, p. 599) 2, p. 599). It also has been quoted from Imam Reza (AS): “Do not seek guidance from things other than the Qur'an for you will be misled" (Ibn Babawayh, 1372, vol. 1, p. 62). Imam al-Sadiq (AS) also said: "The memorizer of the Qur'an who acts on its instructions is along with the honorable, virtuous angels. (Reyshahri, 2005, vol. 9, p. 145). It is clear that when referring to the Holy Quran, every wise reader considers its verses and sentences to be related due to their continuity and togetherness. In other words, he uses the context to understand its meanings.

As a result, it is a sign of approval of the current text and the existing contexts in it by pure Imams (PBUT) when they encourage people to refer to the current Qur'an and consider it as a factor of guidance of people. Therefore, if the opposite was true and the context of the verses was not correct, explanations and corrections would have been made by the Imams to prevent people from misunderstanding. In addition to the arguments given to prove the rule of context, it should be noted that in the Holy Qur'an there are few cases in which the continuity of revelation or their thematic unity is not obvious, and to understand the relationship between the verses it is necessary to notice to other items such as the narrations below the verse, the tone and the tone of the speaker and the purpose of the speaker. For example, the verse of purification "Verily, Allah's Will is to remove away impurity from you, the people of the Messenger's Household and to purify you with a thorough purification" (al-Ahazāb/33) is clearly different from the verses before and after it. Either in terms of the gender of the pronouns that are masculine, while at the beginning of the verse the pronouns are feminine, or in terms of the tone and type of expression, the tone of the end of which is different from the obligatory expressions of the first verse. Therefore, it is possible to deduce from these differences their lack of thematic connection with each other, considering the many narrations that do not express the previous and next sentences in the expression of this honored verse, and conclude that the verse is specific to the Prophet of Islam (PBUH), Imam Ali (AS), Hadrat Fatima (AS), Imam Hassan and Imam Hussein (AS). (Mo'addab, 1392, p. 101)

\section{7- Functions of Siyāq:}

For context, ten functions can be summarized.

\section{7-1 Explanation of Qur'anic Words:}

In many cases, commentators have determined the meaning of a word after mentioning the different meanings of a word with the help of context. For example, in the holy verse (al-Baqarah/ 116), Tabarī has written in the interpretation of the mentioned verse that Qunūt has these meanings in Arabic 
words. Obedience, rebellion and restraint of the word. Then he said: "The best meaning of Qunūt in this verse, according to the context and the previous sentences, is obedience and confession of servitude to God." (Ṭabarī, 1375, vol. 1, p: 403).

\section{7-2 Determining the Purpose of the Verse:}

Other uses of context include determining the purpose of a verse and interpreting it. For example, in the interpretation of verse 4 of Surah al-Burūj , Faḍlullāh has used the context of the verses to understand the meaning, and while expressing the different opinions under the verse, he makes it clear that according to the context of the verse, which is to express divine wrath against the persecutors of believers, In this verse, the meaning of "killed" is the curse and request for the destruction of the oppressors and the rebels, who are the "makers of the fire ${ }^{3 "}$, and it cannot be considered as a means of expressing the murder of the believers. Because in that case, the "makers of the fire" are the believers who have been killed. This statement has nothing to do with the context of the verses. (Faḍlullāh, 1419 AH, 24/167).

\section{7-3 Determining Whether the Verse Is Makkī or Madanī with the Help of Siyāq:}

Recognizing the Meccan or Madan̄ nature of surahs and verses plays an important role in interpretive interpretations, and one of the methods of this recognition is the context of the verses. Like the first verses of Surah al-Ankabūt, which some commentators consider Madanī due to the narrations that follow these verses. However, in these verses, there is a talk of testing the faith of the believers and persecuting the unbelievers towards the believers, which shows that the verses are Meccan (Tabarī, 1996, vol. 10, p. 121).

\section{7-4 Occurrence of the Verse in the Siyāq:}

In some cases, the occurrence of the verse can be confirmed by context. For example, Tabataba'i says in verse 28 of al-Ahzāb: "O Prophet! Say to thy Consorts: If it be that ye desire the life of this World, and its glitter, then come! I will provide for your enjoyment and set you free in a handsome manner." terms that have been used in the verse do not show the complaints some of the wives of the Prophet database. (PBUH). But being exact in the context of the verses, it can be seen that some of his wives were not satisfied with the material life situation in their home and complained about it and wanted to live a better life and adorn the world for themselves. (Tabataba'i, 1350, vol. 16, p. 305).

\section{7-5 Specifying Pronoun Reference:}

The context of the verses can also be used to determine the reference of the pronoun. For example, in determining the reference of the pronoun "they know it" in the verse "The People of the Book know this as they know their own sons" (al-Baqarah/146) paying attention to the context, the pronoun (it) in (they know it) does not refer to the book. Because the context is about the dispute of the well-read with the Holy Prophet (PBUH) and about his prophecy so the pronoun "it" in this verse goes back to the Holy Prophet (PBUH), also comparing his knowledge to (as they know their sons) confirms this meaning. (Faḍlullāh, 1419 AH, vol. 3, pp. 90-91).

\section{7-6 Specific Interpretation of the Verse According to the Siyāq:}

Some verses have a general meaning, but according to the context of the verses, a specific meaning is understood from it, which is the desire of the verse. For example, Surah al-Ahzāb, verse 2: "But follow that which comes to thee by inspiration from thy Lord: for Allah is well acquainted with (all) that ye do." the meaning of the verse seems to be general and broad. However, according to the previous context, which says, "O Prophet! Fear Allah, and hearken not to the Unbelievers and the Hypocrites" it can be said that the verse in question was in the context of the prohibition of the previous verse and was aimed to obey the

3 
revelation which is about disobeying the infidels and hypocrites. And the final sentence of the verse which said "verily Allah is full of Knowledge and Wisdom" indicates this special meaning along with the general and broad meaning of the verse (Tabataba'i, 1350, vol. 16, p. 274).

\section{7-7 Preference and Determination of One of the Recitations:}

In some words, several readings have been included, one of which can be preferred through the context. For example it the verse "And verily Exalted is the Majesty of our Lord: He has taken neither a wife nor a son." (Al-Jinn/3) the word "verily" has been recited both with the "e" and with the "a" which according to the context which is the saying of the Jinn, the recitation with the "e" is superior to "a". However, in the current Qur'an has been written with "a".

\section{7-8 Understanding a Deleted Word or Sentence Using Siyāq:}

Sometimes the mention of the beginning or the news, the subject or the verb of the condition or the punishment and the precedent or the consequence in one verse, reveals what is omitted from the titles in the other verse. Like:

"To the Thamud people (We sent) Salih, one of their own brethren: He said:" O my people! Worship Allah. Ye have no other god but Him. Now hath come unto you a clear (Sign) from your Lord! This she-camel of Allah is a Sign unto you: So leave her to graze in Allah's earth, and let her come to no harm, or ye shall be seized with a grievous punishment." (al-A 'rāf/73) to determine the omitted verb it can be seen from another verse:

"We sent Noah to his people. He said:" O my people! Worship Allah! Ye have no other god but Him. I fear for you the Punishment of a dreadful Day!" (Al-A'rāf/59) that the deleted verb is "We sent".

\section{7-9 Determining the Order of Revelation of Some Verses:}

According to Allameh Tabataba'i, the beginning of verse 3 of Surah Al-Mā'idah, which is about the sanctity of the dead, etc., is not related to the end of the verse, which is the discussion of completing the religion and the completion of blessings (Tabataba'i, 1350, vol.5, p. 168).

\section{7-10 Quoting the Reason of Revelation and Its Acceptance or Non-Acceptance:}

Since knowing the cause of revelation plays an important role in understanding and interpreting the verse, we achieve this with the help of context. Allameh Tabataba'i in interpretation of verses 1 and 2 of Surah al-Aḥāb which was mentioned, since the verse is in the context of prohibition, it can be obtained that the infidels asked for some affairs from the Holy Prophet (PBUH) and the hypocrites insisted on him accepting the offer of the disbelievers. Therefore, according to the context of the verse, it is possible to accept the narrations that have been revealed due to the revelation. (Ibid. Vol. 16, p. 247).

\section{Conclusion}

The following is what can be concluded from the present article:

1. Many scholars of Qur'anic sciences have specified the effect of context on understanding the meaning of the word and the contents of verses and have mentioned four types of context including the context of words, sentences, verses and surahs.

2. Context has many functions such as its role in word interpretation, breadth and narrowness of words, determining the meaning of a sentence, criticizing the causes of revelation, recognizing Makki verses from Madanī, criticizing interpretive hadiths, determining the reference of the pronoun, understanding 
the deleted word or sentence, determining the instance of the word and Preference and determining one of the two readings for a verse in the interpretation of the Holy Quran.

3. Context and rhetoric are related to each other due to the rule of reason, and the listener of the word will find the purpose of the speaker in accordance with the conditions of the speech.

4. The realization of the context of verses and the context of sentences depends on the existence of two conditions of issuance connection and thematic connection.

5. Ways to prove the rule of context include the authenticity of the context, the confinement of the current order of the verses, and the confirmation of the reference to the current Qur'an by the Infallible Imams (As).

6. Examining the context has various functions such as explaining Qur'anic words, determining the purpose and determining whether the verses are Meccan or Madanī, determining the reference of pronouns, preferring and determining one of the readings, understanding the deleted word or sentence in the verse, determining the order of revelation of some verses, quoting The reason of revelation and its acceptance or non-acceptance and the occurrence of the verse due to the context.

\section{Resources}

The Holy Qur'an

Āl Sa'di, Abdul Rahman Ibn Nasser (1408 AH). Taysir al-Karim al-Rahman, Maktabah al-Nihzah alArabīyya, Beirut.

Ālūsī, Seyyed Muhammad (1415 AH). Rūh al-Ma'ān̄̄ fi Tafsir al-Qur'an al-Azim, Dar al-Kutub alIlmīyyah, Beirut.

Azarnoosh, Azartash. (1379 HS). Contemporary Arabic-Persian culture, Publications: Ney, Tehran.

Bahrānī, Seyyed Hashem (1100 AH). Al-Burhān Fi Tafsir al-Qur'an, Bi'thah Foundation, Tehran.

Faḍlullāh, Muhammad Hussein (1419 AH). Min Waḥy al-Qur'an, Dar al-Malik for printing and publishing, Beirut.

Farāhīdī, Khalil Ibn Ahmad (1409 AH). Al-Ayn, Hijrat, Qom.

Fayyūmī, Ahmad Ibn Muhammad (770 AH). Miṣbāḥ Al-Munīr Fi Gharīb al-Sharh al-Kabīr al-Rāfi'ī, Institute for research and publication of knowledge of Ahl al-Bayt, Qom.

Gerami, Mohammad Ali (1383 HS). Knowledge of Qur'an ,Minhāj, Qom.

Ibn Babawayh, Mohammad Ibn Ali.(1372 HS).Translated by Uyūn Akhbār al-Reza(AS),Publisher: Tehran.

Ibn Manẓūr, Muhammad Ibn Mukarram. (630-711 AH). Lisān al-Arab, translator: 'Abulfaḍl Jamālī, publisher: Beirut.

Kawāz, Muhammad Karim (1386 HS). Stylistics of the adult miracle of the Qur'an, translated by Seyyed Hossein Seyyedi, Publications: Sokhan, Tehran.

Khațīb Qazwīn̄̄,Jalāluddīn Muhammad(2010 AD).Ilizah Ulūm al-Balāghah,Dar al-Kutub al-Ilmīya, Beirut.

Kulaynī, Muhammad Ibn Ya’qub (232 AH). Usūl Kāfī, Translator: Muhammad Bāqir Kamaraei, Publications: Uswah, Tehran.

Ma’refat, Mohammad Hadi. (1388 HS). Al-Tamhīd Fi Ulūm al-Qur'an, Islamic Publishing, Qom. 
Miṣbāḥ Yazdī, Muhammad Taqī (1386 HS). Qur'an Knowledge, Imam Khomeini Educational and Research Institute Publications, Qom.

Mo 'addab, Seyyed Reza. (1392 HS). Methods of interpreting the Qur'an, Ishrāq, Qom.

Muhammad ibn Muhammad ibn Arafat al-Warghami Abu Abdullah (2008 AD). Tafsir Ibn Arafa, Researcher: Jalal al-Suyūṭ̂, Publisher: Dar al-Kutub al-Ilmīyyah.

Muhammadi Rey Shahri, Mohammad (1384 HS). Mīzān al-Ḥikmah, Dar al-Hadith, Qom.

Mustafawī, Hassan. (1368 HS). Investigation in the words of the Holy Qur'an, Publisher: Ministry of Culture and Islamic Guidance, Tehran.

Qasim, Mohammad Ahmad; Deeb; Muhȳ̄ al-Din. (2003 AD), Ulūm al-Balāghah (Al-Badi', Al-Bayān and Al-Ma'ānī), Publisher: Al-Hadith Foundation for Books, Tripoli, Lebanon.

Rāghib Isfihān̄̄, Hussein Ibn Muhammad (1412 AH). Al-Mufradāt Fi Gharīb Al-Qur'an, Dar al-Ilm al-Dar al-Shāmiyya, Damascus, Beirut.

Rajabi, Mahmoud et al. (1394 HS). Methodology of Qur'anic interpretation, published by the seminary and university research, Qom.

Rashid Reza, Muhammad. (1354 HS). Tafsir al-Manār, Dar al-Ma'rifah, Beirut.

Șadr, Seyyed Muhammad Bāqir (1392 HS). Courses in the science of Ușūl, the first circle, Al-Zahra Society (AS), Qom.

Sharif al-Radhi, Muhammad ibn Husain (359 to 406 AH). Haqā’iq al-Ta'wīl fi Mutashābih al-Tanzīl, Institute of Advertising and Publishing the knowledge of Ahl al-Bayt (AS), Qom.

Șubḥī Șālih (1393 HS). Discussions in Qur'anic Sciences, Translator: Mohammad Ali Lisani Fesharaki, Publications: Ehsan, Tehran.

Suyūṭị, Jalāluddīn (1421 AH). Al-Itqān fi Ulūm al-Qur'an, Dar al-Kutub al-Arabī, Beirut.

Ṭabarī Abu Ja'far, Muhammad ibn Jarīr. (1375 HS). Jami’ al-Bayān fi Tafsīr al-Qur'an, Translator: Abu alQasem Payandeh, publications: Institute of Iranian Culture.

Tabataba'i, Seyyed Muhammad Hussein (1350 HS). Al-Mīzān fi Tafsīr al- Qur'an, Islamic Publications Office of the Society of Teachers of the Seminary of Qom.

Tabataba'i, Seyyed Muhammad Hussein (1388 HS). Qur'an in Islam, Islamic Library, Tehran.

Ṭabrasī, Faḍl Ibn Hassan (548 AH). Tafsir Majma' al-Bayān, Translator: Ahmad Beheshti, Publisher: Farahani, Tehran.

Zamakhsharī, Mahmoud Ibn Hammer (1966 AD). Al-Kashshāf, Publications: Cairo.

Zamakhsharī, Mahmoud Ibn Hammer (1966 AD). Asās al-Bālighah, Dar al-Kutub al-Ilmīyyah, Beirut.

Zarkashī, Badruddin Muhammad bin Abdullah (794 AH). Al-Burhān fi Ulūm al-Qur'an, Jidar al-Ma'rifah, Beirut.

\section{Copyrights}

Copyright for this article is retained by the author(s), with first publication rights granted to the journal.

This is an open-access article distributed under the terms and conditions of the Creative Commons Attribution license (http://creativecommons.org/licenses/by/4.0/). 